\title{
GENETIC AND PHENOTYPIC CORRELATIONS FOR BODY WEIGHTS IN YANKASA SHEEP
}

\author{
W.A. HASSAN ${ }^{1,3}$, BUVANENDRAN ${ }^{2}$, N.I. DIM ${ }^{1}$, O. A. OSINOWO ${ }^{2}$ AND B.Y. ABUBAKAR ${ }^{2}$ \\ ${ }^{1}$ Department of Animal Science, Ahmadu Bello University, Zaria, \\ ${ }^{2}$ National Animal Production Research Instituce, Ahmadu Bello University, Zaria, Nigeria. \\ ${ }^{3}$ Department of Animal Science, Usmanu Danfodiyo University Sokoto, Nigeria.
}

(Received October 15, 1990, accepted 21 January, 1991)

\begin{abstract}
Using paternal half-alb (PHS) analysis, coefincients of genetic and phenotypic correlations between body veights of Yankasa lambs at birth, weaning (three months), six months, nine months and one year of age were estimate. The highest genetic correlation coefficient of 0.33 was obtained between birth and yearling weight. Six- month weight had very low and negative genetic correlation with yearling weight $(-0.04)$. Pkenotypic correlation coefficients for the various body weights pairs were positive and mostly of medium magnitude $(0.12-0.47)$.
\end{abstract}

Key words: Tropics, Yankasa sheep, body weights, correlation

\section{INTRODUCTION}

Genetic and phenotypic correlations are essential for predicting indirect responses to selection and for determining the optimum weighting and expected response to selection when improving more than one trait. Very few coefficients of phenotypic correlation are available for the Nigerian breeds of sheep (Buvanendran et al., 1981; Taiwo et al., 1982). No coefficient of genetic correlation between pre- weaning and post-weaning body weights in these breeds has been reported. This study was therefore carried out to obtain coefficients of genetic and phenotypic correlations between body weights of Yankasa lambs at five stages of growth.

\section{MATERIALS AND METHODS}

Records of birth and monthly body weights up to one year of age collected between 1981 and 1985 from an accelerated lambing scheme

Nigeria Journal of Animal Production 18 (1991) project at the National Animal Production Research Institute, Shika, were analysed. The history and management of the flock were as earlier reported (Osinowo, 1982)). Except for birth weight, correlation for differences in the ages of the lambs at weighing at three months, six months, nine months and one year was done by multiplying average daily liveweight gain (ADG) during the period under consideration by the average age of the lamb at each stage (Table 1). Using least squares procedures (Harvey, 1960) the data were adjusted for the effects of type of birth, sex, parity and sire-group (Hassan, 1987). Table 2 gives the least squares mean for lamb weights at the fivestages of growth. With the aid or SPSS sub-program 'Anova', analysis of variance of cross products was employed to obtain components of covariance between breeding values of the growth traits. The covariance and variance components of the traits were used to estimate both the genetic and phenotypic correlations. Genetic correlation, rG, was estimated as:

$r_{G}=\sigma_{s(x)} \sigma_{s(y)} /\left[\begin{array}{lll}\sigma^{2} s(x) & \sigma_{s(y)}^{2}\end{array}\right]^{1 / 2}$

Standard error of this correlation was estimated according to Robertson (1959) thus:

S.E.(rG) $=\frac{1-\mathrm{rG}^{2}}{\sqrt{2}} \sqrt{\frac{\text { S.E. }\left(\mathrm{h}_{\mathrm{x}}{ }^{2}\right) \text { S.E. }\left(\dot{h}_{\mathrm{y}}{ }^{2}\right)}{\mathrm{h}_{\mathrm{x}}{ }^{2} \cdot \mathrm{h}_{\mathrm{y}}{ }^{2}}}$

where:

S.E. $\left(h_{x}{ }^{2}\right)$, S.E. $\left(h_{y}{ }^{2}\right)=$ standard error of heritability of traits $x$ and $y$, respectively.

$\left(h_{x}{ }^{2}\right),\left(h_{y}{ }^{2}\right)=$ heritability of traits $x$ and $y$, respectively. 


\begin{tabular}{|c|c|c|c|c|c|}
\hline \multirow{2}{*}{ 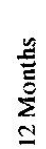 } & هُ & 6 & 독운 & 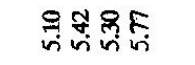 & 당 హ్ల \\
\hline & $\sum^{5}$ & 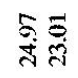 & $\begin{array}{l}\text { की } 8 \\
\text { तु }\end{array}$ & 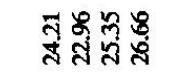 & 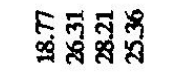 \\
\hline & is & $₹ \pi$ & 果 & ตัทンロ & タேッニ \\
\hline & sis & $\begin{array}{l}\vec{F} \\
\dot{y} \\
\dot{m}\end{array}$ & ఫૈ & ఫ్రి & 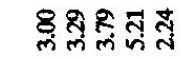 \\
\hline 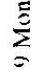 & 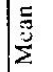 & $\stackrel{\vec{z}}{\sim} \stackrel{\sim}{\sim}$ & $\begin{array}{l}\text { 号: } \\
\text { ते }\end{array}$ & 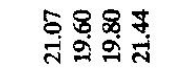 & 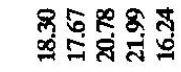 \\
\hline & 운 & $\cong$ ఫ & 鬲\& & 导丈甘 & 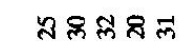 \\
\hline 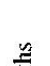 & 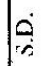 & कृ & 总芯 & 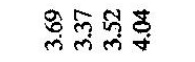 & 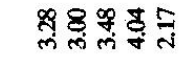 \\
\hline$\sum_{0}^{0}$ & $\sum^{5}$ & 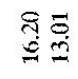 & 疍 & 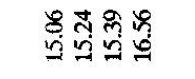 & 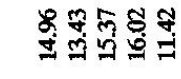 \\
\hline & $i$ & 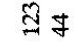 & $8 \%$ & 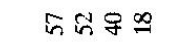 & דెल हిत्र \\
\hline$\cong$ & a & Fे & $\vec{m} \stackrel{8}{8}$ & 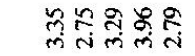 & 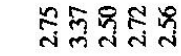 \\
\hline$\sum_{m}^{e}$ & 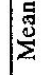 & $\begin{array}{c}\hat{b} \\
= \\
= \\
x\end{array}$ & 施 & 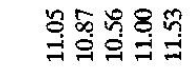 & 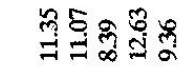 \\
\hline & z & $\stackrel{0}{\pi}$ & $\mathcal{T}:$ & ฌேタタ= & 禺 \& \\
\hline & 官 & :ै & $\stackrel{5}{\circ}:$ & ธㅇㅇㅇㅇㅇㅇ영 & 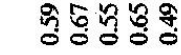 \\
\hline & 虔 & $\underset{\text { ri }}{\stackrel{2}{\text { त् }}}$ & $\sum_{r i} \underset{r i}{\widetilde{\gamma}}$ & 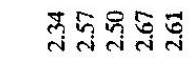 & 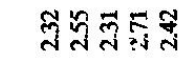 \\
\hline & 28 & 농 & $\stackrel{1}{x} \cong$ & $\widehat{S} \approx 0$ in & チேららの \\
\hline & 㟧 & 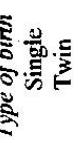 & 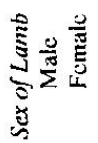 & 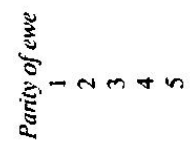 & 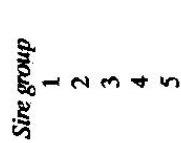 \\
\hline
\end{tabular}




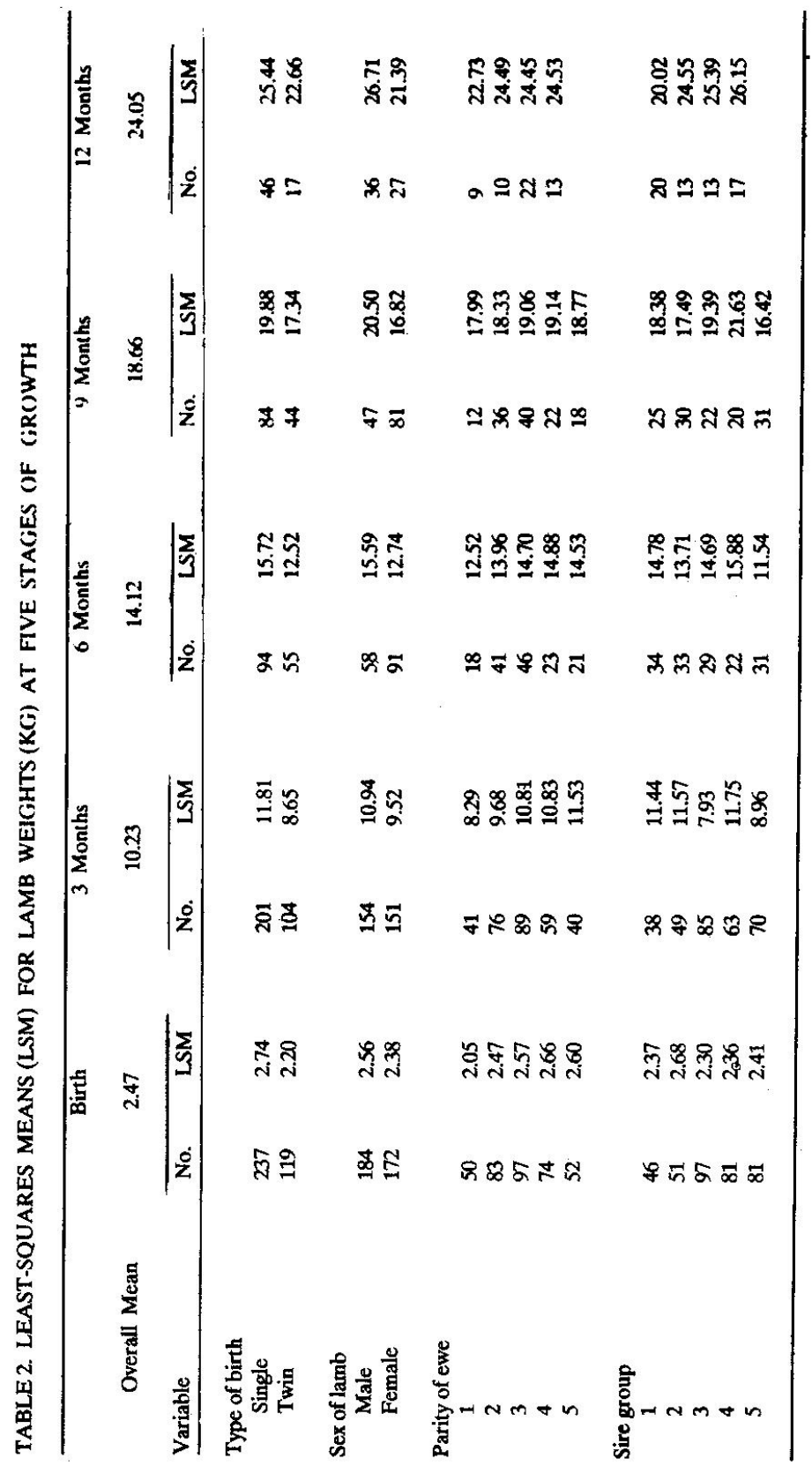




\section{CORRELATIONS IN YANKASA SHEEP}

Phenotypic correlation, $\mathbf{r}_{\mathrm{p}}$, was calculated according to Becker (1968):

$$
r_{p}=\frac{\sigma w(x) \sigma_{w(y)}+\sigma_{s(x)} \sigma_{s(y)}}{\left[\sigma_{w(x)}^{2}+\sigma_{s(x)}^{2}\right]\left[\left(\sigma_{w(y)}^{2}+\sigma_{s(y)}^{2}\right.\right.}
$$

where:

$$
\begin{aligned}
\sigma_{w}(x) w(y)= & \begin{array}{l}
\text { within sire component of } \\
\text { covariance for traits } x \text { and } y . \\
\text { between sire component of } \\
\text { covariance for traits } x \text { and } y .
\end{array} \\
\sigma_{s}(x) s(y) & \begin{aligned}
\sigma^{2} w(x), \sigma^{2} w(y)= & \text { the within sire component of } \\
& \text { variance for traits } x \text { and } y, \\
& \text { respectively. }
\end{aligned} \\
\sigma^{2} s(x), \sigma^{2} s(y)= & \text { the sire component of variance } \\
& \text { for traits } x \text { and } y, \text { respcctively. }
\end{aligned}
$$

\section{RESULTS AND DISCUSSION}

\section{Genetic Correlation}

Table 3 gives the estimates of genetic and phenotypic correlations obtained between all five lamb body weights. The genetic correlation coefficients were generally relatively low, ranging between -0.04 and 0.33 . The coefficient of 0.01 obtained between birth weight and weaning weight was muxh lower than the average of eight estimates (0.49) reported by Ragab et al. (1953),MacNaughton (1956) Gjedrem (1967), Fahmy et al. (1969), Vesely et al. (1970), Thrift et al. (1973), and Raman et al. (1981), ranging from 0.24 to 1.04 . It was however very close to 0.12 , 0.14 and 0.13 reported by Chopra and Acharya (1971), Urala (1978) and Elliot et al. (1979), in
Bikaneri, Bannur and Perendale sheep, $x$ tively. The estiamte of 0.26 obtained bet birth weight and six months weight was 10 than average of three estimates (0.67) reported by Ragabet al. (1953), Urala (1978) and Singh $\epsilon$ al. (1984), with a range of 0.51 to 0,82 . Chopra and Acharya (1971) however reported a smaller and negative estimate $(-0.07)$ for the two traits. The only available estimate to which the coefficient of 0.19 obtained for birth weight and nine month weight can be related is negative (Urala, 1978). The estimate of 0.33 for birth weight and yearling weight compared favourably with 0.32 and 0.37 reported by Fahmy et al. (1968), and Urala (1978) for Barki and. Bannur sheep, respectively.

Estimates for weaning and post-weaning weights in the present study were much lower than reported values (Radomska and Klewiec, 1975; Elliot et al. (1979), Singh et al. (1984), and showed a tendency to decline as the period intervening the weights being related increased, with few exceptions. Acharya and Malik (1971) and Chopra and Acharya (1971) observed a similar trend. This can be attributed to large maternal environmental influence on the weight of lamb at weaning and smaller data size cause by frequent transfers of lambs from the flock to other experiments from weaning till yearling.

Phenotypic correlation

The estimate of 0.17 for coefficient of phenotypic correlation for birth and weaning weights was very close to reported values (Karam, 1959; Butcher et al. (1964), Morsy and

\section{TABLE 3. COEFFICIENTS OF GENETIC AND PHENOTPIC CORRELATIONS BETWEEN WEIGHT (KG) AT FIVE STAGES}

\begin{tabular}{llllll} 
& Birth & Weaning & Six-months & Nine-months & Yearling \\
Birth & & $0.10 \pm 0.29$ & $0.26 \pm 0.30$ & $-0.19 \pm 0.34$ & $0.33 \pm 0.51$ \\
Weaning & 0.17 & & $0.27 \pm 0.20$ & $0.17 \pm 0.22$ & $0.08 \pm 0.37$ \\
Six-months & 0.18 & 0.43 & & $0.14 \pm 0.25$ & $0.04 \pm 0.42$ \\
Nine-months & 0.14 & 0.39 & 0.33 & & $0.18 \pm 0.14$ \\
Yearling & 0.12 & 0.27 & 0.47 & 0.33 & \\
\hline
\end{tabular}

Above diagonal are genetic correlations and below diagonal phenotypic correlations. 
Karam, 1967; Haider and Shah, 1974) in Rahmani, Southdown, Texel and Bibrik sheep respectively. Other workers including Kassab and Karam (1961), Gjedrem (1967), Vesely et al. (1970), Milosavljevic (1971(, Purushotam (1978) and Raman et al. (1981), reported higher estimates of the coefficient $(0.29-0.98)$. The estimate of 0.18 obtained for birth and six month weight in the present study was much lower than 0.43 reported by Buvanendran et al. (1981), using the same breed. The same authors however reported a similar estimate for correlation between the two body weight traits in Uda sheep. The estimate was also very close to values reported by Dzakuma et al. (1978), in Hampshire and Bannur sheep, respectively. The lowest correlation coefficient of 0.12 was folind for birth anc' yearling weights. Karam (1959) reported similar trend in Rahmani sheep.

The present analysis yielded a lower coefficient of correlation (0.43) for weaning and six month weight than 0.71 earlier reported in the same breed (Buvanendran et al. (1981), and 0.55 for the Nigerian Dwarf Sheep (Taiwo et al. (1982). Weaning weight was however found to be more strongly correlated phenotypically with nine and yearling weight than in the latter. The estimate got for six months and yearling weight $(0.47)$ was much lower than the average of values $(0.74)$ reported by Morley (1951), Chopra and Acharya (1971) and Dzakuma et al. (1978) respectivelyin Merino, Bikaneri and Hampshire breeds with a range of 0.70 to 0.78 .

Comparing the estimates obtained for both genetic and phenotypic correlations for various body weight pairs in the present study, coefficients of genetic correlation of birth weight with post-weaning weights tended to be higher than those of the corresponding phenotypic correlation. This agreed with Ragab et al. (1953), and Besset et al. (1967), who attributed the finding to the fact that phenotypic correlation contains an environmental component as well as the genetic one, while genetic correlation measures only the additive effect of genes that affect two traits in the same animal plus some epistasis effect. Also lower estimates were obained for genetic correlation between weaning and post-weaning weights compared to those of phenotypic correlation but both agreed in direction.

The magnitude of the coefficients obtained in the present flock indicated that some proportion. of genetic gain from selection on weaning weight might be carried on to weights at six and nine months of age. Larger data set would however be required to validate this in the Yankasa sheep.

\section{ACKNOWLEIXGEMENT}

The authors of this paper wish to thank the Director of teh National Animal Production Research Institute, Zaria, for providing the facilities for the study.

\section{REFERENCES}

ACHARYA, R. M. and MALIK R. C., 1979. Genetic and Phenotypic parameters for pre- and post-weaning body weights in Nali and Lohi and their crosses with Nellore and Mendya. Indian J. Anim. Sci., 42(2) : 1126.

BASSETT, J. W., CARTWRIGHT, T. C., VAN HORN, J. L. and WILSON, F. S. 1967. Estimates of genetic and phenotypic parameters of weaning and yearling traits in range Rambouillet ewes. J. Anim. Sci. 26 : 254.

BECKER, W. A. 1968. Manual of Quantitative Genetics Academic Enterprises, Pullman W. A. 99163-0666 USA.

BUTCHER, E. L., DUNBAR, R. S. (Jr) and WELSH, J. A., 1964. Heritabilities of and the correlations between lamb birth weight and 140-day weight. J. Anim. Sci., $23: 12$.

BUVANENDRAN, V., ADU, I. F., and OYEJOLA B. A. 1981. Breed and Environmental Effects on lambs production in Nigeria. J. Agric. Sci. (Camb.) $96: 9$.

CHOPRA, S. C., ACHARYA, R. M., 1971.

Genetic and Phenotypic parameters of body weights in Bikaneri sheep (Magra strain) Anim. Prod. $13: 343$. 
D7.AKUMA, J. M., NIELSEN, M. K. and DOANE T. H., 1978. Cicnetic and Phenotypic parameters estimates for growth and wool traits in Hampshire sheep. J. Anim. Sci. 47 : 1014.

ELI.IO)T, K. H., RAO, A. L. and WICKMANG. A. 1979. Analysis of Perendale flock II. Geretic and phenotypic parameters for im-

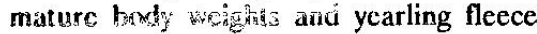
chardactistics, New Zealand J. Agric. Res., $22: 267$.

FAHMY, M. H., GALAL, E.S.E., GHANEM Y. S. and KHISHIN S. S. 1968. Genetic parameters of Barki sheep raised under scmi-arid conditions. Anim. Prod. 10:361.

GJEDREM, T. 1967. Phenotypic añ genetic parameters of lamb at five ages. Acta Agriculure Scandinavica. 17: 199.

HAIDER, U., and SHAH, S. K. 1974. Relation ship between body weight of Harnai and Bibrik ewes and birtha nd weaning weights c. ${ }^{c}$ their lambs. Agriculture Parkistan. 25(3) : 209.

HARVEY, W. B. 1960. Least squares analysis of data with unequal sub-class numbers. United States Department of Agriculture, ARS - 20-8 (Mimeograph).

HASSAN, W. A. 1987. Genetic and Environmental effects on the growth rate of Yankasa lambs. Unpublished M.Sc. Thesis. Ahmadu Bello University, Zaria, pp. 161.

KARAM, H. A. 1959. Birth, weaning and yearling weights of Rahmani sheep. I. Effects of some environmental facto:s II. Heritability estimates and correlations. Empire J. Exptal. Agric. 27 (108) : 313.

KASSAB S. A., KARAM, H. A. 1961. Effects of some environmental factors on body and fleece weight in Barki sheep. J. Anim. Prod. U.A.R., $1: 149$.
MACNAUGHTON, W. N. 1956. Repeatability and heritability of birth, weaning and shearing weights among range sheep in Canada. Anim. Breed. Abst. $25: 1926$ (Abstr.).

MORLEY, F.W.H. 1951. Selecion for economic characters in Ausiralian Merino sheep. I. Estimates of phenotypic and genetic parameters Sci. Bull. N.S.W. Dept. Agric. No. 73.

MORSY, M. M. and KARAM, H. A. 1967. Body weights and mortality rates among Texel lambs at the Tahreer Province in Egypt.J. Ani. Prod. UAR., $5: 65$.

OSINOWO, O.A. 1982. Oestrus synchronization, artificial insemination and early rebreeding in Yankasa sheep. Nigerian $J$. Anim. Prod. 9(2) : 107.

PURUSHOTAM, C. H. 1978. Comparative study of the production and reproductive traits of Nellore and Mandya sheep. Thesis Abstr. Haryana Agric. Univ. 4 (2) : 99 (Abstr.).

RADOMSKA, M. J. and KLEWIEC, J., 1975. Comparative analysis of certain Romney Marsh flocks. II. Genetic parameters. Anim. Breed. Abstr. 44 : 1201.

RAGAB, M. T., ASKER A. A. and KADI M. R., 1953. Genetic factors affecting weights of Ossimi lambs. Empire J. Expert. Agric. 21 : 304 .

RAMAN, K. S., MANI, V., and ARUMUGHAM, M. P., 1981. Production performance of Stavropol Meino-weaning weight. Indian Vet. J. (11) : 889.

ROBERTSON, A. 1959. Sampling variance of genetic correlation coefficient. Biometrics 15 : 469 .

SINGH, B. CHOPRA, S.C. and ARORA, C. L. 
1984. Genetic analysis of some economic traits in Russian Merino sheep. Indian Vet. J., $61: 866$.

THRIFT, F. A. WHITEMAN, J. V. and KRAT ZER, D. D. 1973. Genetic analysis of preweaning and post-weaning lamb growth traits. J. Anim. Sci., 36 (4) : 640.
URALA, K.A.R. 1978. Genetic studies on body weights in Bannur sheep. Thesis Abstr. Haryana Agric. Univ., 4 (1) : 23.

VESELY, J. A., PETERS, H. F. GLEN, S. B. and ROBINSON, O. W., 1970. Heritabilities and genetic correlations in growth and wool traits of Ramboilett and Romnelet sheep. J. Anim. Sci., $30: 174$. 